TechnoLEARN: An International Journal of Educational Technology

TechnoLEARN: 9(2): 125-132, December 2019

DOI: $10.30954 / 2231-4105.02 .2019 .10$

(C2019 New Delhi Publishers. All rights reserved

\title{
Education in the Vision of Swami Vivekananda
}

\section{Madhulata Pal}

Research Scholar, Jiwaji University, Gwalior, Madhya Pradesh, India

Corresponding author: dubeymadhulata1@gmail.com

\begin{abstract}
In this paper, we would analyse about Swami Vivekananda's views on Philosophy of Education. According to Swami Vivekananda, education does not mean the mass of information which is inserted by force into the mind of a child. In his own words, education is the manifestation of perfection already reached man. Indian nationalism and spiritualism were the basic foundations for his philosophy of education and the philosophy of Vedant and Upanishads. He was against the system of contemporary educational system; it turned men into slaves, capable of slavery and nothing else. He emphasized that the aim of education to be life-building, man-making and charactermaking and also he said that knowledge without culture was only skin-deep. Swamiji attempts to establish, through his words and deeds, that the end of all education is man making. He prepares the scheme of this man-making education in the light of his over-all philosophy of Vedanta. According to Vedanta, the essence of man lies in his soul, which he possesses in addition to his body and mind. In true with this philosophy, Swamiji defines education as 'the manifestation of the perfection already in man.' The aim of education is to manifest in our lives the perfection, which is the very nature of our inner self. This perfection is the realization of the infinite power which resides in everything and every-where-existence, consciousness and bliss (satchidananda). In his scheme of education, Swamiji lays great stress on physical health because a sound mind resides in a sound body. He often quotes the Upanishadic dictum 'nayamatmabalahinenalabhyah'; i.e. the self cannot be realized by the physically weak. Education for him means that process by which character is formed, strength of mind is increased, and intellect is sharpened, as a result of which one can stand on one's own feet.
\end{abstract}

Method or Procedure: According to him, knowledge is inherent in every man's soul. What we mean when we say that a man 'knows' is only what he 'discovers' by taking the cover off his own soul. Consequently, he draws our attention to the fact that the task of the teacher is only to help the child to manifest its knowledge by removing the obstacles in its way. In his words: 'Thus Vedanta says that within man is all knowledge even in a boy it is so and it requires only an awakening and that much is the work of a teacher.' Swamiji lays a lot of emphasis on the environment at home and school for the proper growth of the child. 
CPal

Fields of Study: Vivekananda, in his scheme of education, meticulously includes all those studies, which are necessary for the all-around development of the body, mind and soul of the individual. Why religion forms the very foundation of education becomes clear in his following words: 'In building up character, in making for everything that is good and great, in bringing peace to others, and peace to one's own self, religion is the highest motive power, and, therefore, ought to be studied from that standpoint. Swamiji believes that if education with its religious core can invigorate man's faith in his divine nature and the infinite potentialities of the human soul, it is sure to help man become strong, yet tolerant and sympathetic. It will also help man to extend his love and good will beyond the communal, national and racial barriers.

Keywords: Character building, Humanism, Man-making, Self-confidence, SelfEducation, and Sympathy.

Swami Vivekananda (1863 - 1902), a great thinker and reformer of India, embraces education, which for him signifies 'man-making', as the very mission of his life. In this paper, which purports to expound and analyze Vivekananda's views on education, an endeavor has been made to focus on the basic theme of his philosophy, viz. the spiritual unity of the universe. Whether it concerns the goal or aim of education, or its method of approach or its component parts, all his thoughts, we shall observe, stem from this dormant theme of his philosophy which has its moorings in Vedanta.

Vivekananda realizes that mankind is passing through a crisis. The tremendous emphasis on the scientific and mechanical ways of life is fast reducing man to the status of a machine. Moral and religious values are being undermined. The fundamental principles of civilization are being ignored. Conflicts of ideals, manners and habits are pervading the atmosphere. Disregard for everything old is the fashion of the day. Vivekananda seeks the solutions of all these social and global evils through education. With this end in view, he feels the dire need of awakening man to his spiritual self wherein, he thinks, lies the very purpose of education.

\section{Vivekananda's Philosophy of Education}

The real education according to Swami Vivekananda is that which prepares the individual for struggle for existence. Education prepares a man for social service, to develop his character and finally iambuses him with the spirit and courage of a lion. For getting degree is not an education, the proper education must be viewed on the basis of character, mental powers, intelligence and inculcates. Self-confidence and self-reliance in the individuals. Swamiji has emphasized that all the knowledge which we gets from worldly or spiritual lies embedded in the human mind. It was covered with a veil of darkness and ignorance. Education is a tool to open from the darkness and ignorance, after getting of education, the knowledge will shines out dazzlingly. The teaching and learning are the one way of process. The teacher only guides, suggests, points out and helps the student. Self-learning and self getting knowledge 
Education in the Vision of Swami Vivekananda $\mathcal{P}$

is the real education. The teacher only motivates and encourages the students to find out the hidden treasure of knowledge that lies dormant within him. He condemned and refused the bookish learning and rote memory education. Condemning the theoretical and academic education, he spoke emphatically for practical and experimental education. He warned his countrymen saying "you will have to be practical in all spheres of work. The whole country has been ruined by mass theories."

\section{The Goal or Objective of Education}

Vivekananda points out that the defect of the present-day education is that it has no definite goal to pursue. A sculptor has a clear idea about what he wants to shape out of the marble block; similarly, a painter knows what he is going to paint. But a teacher, he says, has no clear idea about the goal of his teaching. Swamiji attempts to establish, through his words and deeds, that the end of all education is man making. He prepares the scheme of this manmaking education in the light of his over-all philosophy of Vedanta. According to Vedanta, the essence of man lies in his soul, which he possesses in addition to his body and mind. In true with this philosophy, Swamiji defines education as 'the manifestation of the perfection already in man.' The aim of education is to manifest in our lives the perfection, which is the very nature of our inner self. This perfection is the realization of the infinite power which resides in everything and every-where-existence, consciousness and bliss (satchidananda). After understanding the essential nature of this perfection, we should identify it with our inner self. For achieving this, one will have to eliminate one's ego, ignorance and all other false identification, which stand in the way. Meditation, fortified by moral purity and passion for truth, helps man to leave behind the body, the senses, the ego and all other non-self elements, which are perishable. He thus realizes his immortal divine self, which is of the nature of infinite existence, infinite knowledge and infinite bliss.

At this stage, man becomes aware of his self as identical with all other selves of the universe, i.e. different selves as manifestations of the same self. Hence education, in Vivekananda's sense, enables one to comprehend one's self within as the self everywhere. The essential unity of the entire universe is realized through education. Accordingly, man making for Swamiji stands for rousing mans to the awareness of his true self. However, education thus signified does not point towards the development of the soul in isolation from body and mind. We have to remember that basis of Swamiji's philosophy is Advaita which preaches unity in diversity. Therefor, man making for him means a harmonious development of the body, mind and soul. Vivekananda wanted all-round development of education to heart and mind, to strengthen character and national consciousness, to help in the cultivation of strength and energy, nurture the brain and intellect and stir feelings of kindness and sympathy. He emphatically said: 
CP Pal

"We want that education by which character is formed, strength of mind is increased, the intellect is expanded and by which one can stand on one's own feet. What we need is to study, independent of foreign control, different branches of the knowledge that is our own and with it the English language and Western science; we need technical education and all else that will develop industries. So that men, instead of seeking for service, may earn enough to provide for them and save against a rainy day. The end of all education, all training, should be man-making. The end and aim of all training is to make the man grow. The training, by which the current and expression of will are brought under control and become fruitful, is called education. What our country now wants are muscles of iron and a nerve of steel, gigantic wills which nothing can resists, which can penetrate into the mysteries and secrets of the universe and will accomplish their purpose in any fashion, even if it means going down to the bottom of the ocean, meeting death face to face. It is a man-making religion that we want. It is man-making theories that we want. It is man-making education all round that we want."

In his scheme of education, Swamiji lays great stress on physical health because a sound mind resides in a sound body. He often quotes the Upanishadic dictum 'nayamatmabalahinenalabhyah'; i.e. the self cannot be realized by the physically weak. However, along with physical culture, he harps on the need of paying special attention to the culture of the mind. According to Swamiji, the mind of the students has to be controlled and trained through meditation, concentration and practice of ethical purity. All success in any line of work, he emphasizes, is the result of the power of concentration. By way of illustration, he mentions that the chemist in the laboratory concentrates all the powers of his mind and brings them into one focus-the elements to be analyzed-and finds out their secrets. Concentration, which necessarily implies detachment from other things, constitutes a part of Brahmacharya, which is one of the guiding mottos of his scheme of education. Brahmacharya, in a nutshell, stands for the practice of self-control for securing harmony of the impulses. By his philosophy of education, Swamiji thus brings it home that education is not a mere accumulation of information but a comprehensive training for life. To quote him: 'Education is not the amount of information that is put into your brain and runs riot there undigested, all your life.' Education for him means that process by which character is formed, strength of mind is increased, and intellect is sharpened, as a result of which one can stand on one's own feet.

\section{Method or Procedure}

Having analyzed the goal or objective of education, the next question that naturally arises is about the method of imparting education. Here again, we note the Vedantic foundation of Swamiji's theory. According to him, knowledge is inherent in every man's soul. What we mean when we say that a man 'knows' is only what he 'discovers' by taking the cover off 
his own soul. Consequently, he draws our attention to the fact that the task of the teacher is only to help the child to manifest its knowledge by removing the obstacles in its way. In his words: 'Thus Vedanta says that within man is all knowledge even in a boy it is so and it requires only an awakening and that much is the work of a teacher.' To drive his point home, he refers to the growth of a plant. Just as in the case of a plant, one cannot do anything more than supplying it with water, air and manure while it grows from within its own nature, so is the case with a human child. Vivekananda's method of education resembles the heuristic method of the modern educationists. In this system, the teacher invokes the spirit of inquiry in the pupil who is supposed to find out things for himself under the bias-free guidance of the teacher. Swamiji lays a lot of emphasis on the environment at home and school for the proper growth of the child. The parents as well as the teachers should inspire the child by the way they live their lives. Swamiji recommends the old institution of gurukula (living with the preceptor) and similar systems for the purpose. In such systems, the students can have the ideal character of the teacher constantly before them, which serves as the role model to follow. Although Swamiji is of the opinion that mother tongue is the right medium for social or mass education, he prescribes the learning of English and Sanskrit also. While English is necessary for mastering Western science and technology, Sanskrit leads one into the depths of our vast store of classics. The implication is that if language does not remain the privilege of a small class of people, social unity will march forward unhampered.

\section{Vivekananda's Principles of Education}

Like Rabindranath Tagore, Vivekananda also prescribed the same ancient spiritual methods of teaching, where Guru and his disciples lived in close association as in a family. The following are the basic principles of education.

(i) Education is not only for getting information; rather it should develop character, mental powers, intelligence and inculcate self-confidence together with self-reliance.

(ii) Education should develop the child physically, mentally and spiritually.

(iii) While giving educational qualification, the technical education was necessary for the industrial growth which would lead to the economic prosperity of the nation.

(iv) Practicing of Brahmacharya is very essential for getting knowledge. The concentration is the key to all the knowledge.

(v) Religious education should be imparted through sweet impressions and fine conduct in preference to books.

(vi) Education should be foster spiritual faith, devotion and self-surrender in the individual and should foster full development through service and sacrifice. 
\%

$\mathrm{Pal}$

(vii) Education should develop character, mental powers, intelligence and inculcate selfconfidence together with self-reliance.

(viii) All the subjects must be included in the curriculum which promotes the material and spiritual advancement of a child.

\section{Fields of Study}

Vivekananda, in his scheme of education, meticulously includes all those studies, which are necessary for the all-around development of the body, mind and soul of the individual. These studies can be brought under the broad heads of physical culture, aesthetics, classics, language, religion, science and technology. According to Swamiji, the culture values of the country should form an integral part of the curriculum of education. The culture of India has its roots in her spiritual values. The time-tested values are to be imbibed in the thoughts and lives of the students through the study of the classics like Ramayana, Mahabharata, Gita, Vedas and Upanishads. This will keep the perennial flow of our spiritual values into the world culture. Education, according to Swamiji, remains incomplete without the teaching of aesthetics or fine arts. He cites Japan as an example of how the combination of art and utility can make a nation great. Swamiji reiterates that religion is the innermost core of education. However, by religion, he does not mean any particular kind of it but its essential character, which is the realization of the divinity already in man. He reminds us time and again that religion does not consist in dogmas or creeds or any set of rituals. To be religious for him means leading life in such a way that we manifest our higher nature, truth, goodness and beauty, in our thoughts, words and deeds. All impulses, thoughts and actions which lead one towards this goal are naturally ennobling and harmonizing, and are ethical and moral in the truest sense. It is in this context that Swamiji's idea of religion, as the basis of education should be understood. We note that in his interpretation, religion and education share the identity of purpose.

Why religion forms the very foundation of education becomes clear in his following words: 'In building up character, in making for everything that is good and great, in bringing peace to others, and peace to one's own self, religion is the highest motive power, and, therefore, ought to be studied from that standpoint. Swamiji believes that if education with its religious core can invigorate man's faith in his divine nature and the infinite potentialities of the human soul, it is sure to help man become strong, yet tolerant and sympathetic. It will also help man to extend his love and good will beyond the communal, national and racial barriers.

It is a misinterpretation of Vivekananda's philosophy of education to think that he has overemphasized the role of spiritual development to the utter neglect of the material side. Vivekananda, in his plan for the regeneration of India, repeatedly presses the need for the eradication of poverty, unemployment and ignorance. He says, We need technical education and all else which may develop industries, so that men, instead of seeking for service, may 
earn enough to provide for them-selves, and save something against a rainy day. He feels it necessary that India should take from the Western nations all that is good in their civilization. However, just like a person, every nation has its individuality, which should not be destroyed. The individuality of India lies in her spiritual culture. Hence in Swamiji's view, for the development of a balanced nation, we have to combine the dynamism and scientific attitude of the West with the spirituality of our country. The entire educational program should be so planned that it equips the youth to contribute to the material progress of the country as well as to maintaining the supreme worth of India's spiritual heritage.

Another important aspect of Swamiji's scheme of education is women's education. He realizes that it if the women of our country get the right type of education, then they will be able to solve their own problems in their own way. The main objective of his scheme of female education is to make them strong, fear-less, and conscious of their chastity and dignity. He observes that although men and women are equally competent in academic matters, yet women have a special aptitude and competence for studies relating to home and family. Hence he recommends the introduction of subjects like sewing, nursing, domestic science, culinary art, etc which were not part of education at his time.

\section{CONCLUSION}

The exposition and analysis of Vivekananda's scheme of education brings to light its constructive, practical and comprehensive character. He realizes that it is only through education that the uplift of masses is possible. To refer to his own words: Traveling through many cities of Europe and observing in them the comforts and education of even the poor people, there was brought to my mind the state of our own poor people and I used to shed tears. When made the difference? "Education" was the answer I got.'

He states it emphatically that if society is to be reformed, education has to reach everyonehigh and low, because individuals are the very constituents of society. The sense of dignity rises in man when he becomes conscious of his inner spirit, and that is the very purpose of education. He strives to harmonize the traditional values of India with the new values brought through the progress of science and technology.

It is in the transformation of man through moral and spiritual education that he finds the solution for all social evils. Founding education on the firm ground of our own philosophy and culture, he shows the best of remedies for today's social and global illness. Through his scheme of education, he tries to materialize the moral and spiritual welfare and upliftment of humanity, irrespective of caste, creed, nationality or time. However, Swami Vivekananda's scheme of education, through which he wanted to build up a strong nation that will lead the world towards peace and harmony, is still a far cry. It is high time that we give serious thought to his philosophy of education and remembers his call to every-body-'Arise, awake, and stop not till the goal is reached. 
¿Pal

\section{REFERENCES}

Chandra, S.S. and Rajendra K. Sharma, Philosophy of Education, New Delhi: Atlantic Publishers and Distributors (p) LTD, 2004, p. 212.

Eastern and Western Disciples, Life of Swami Vivekananda, Two Volumes. Kolkata: AdvaitaAshrama, www. advaitaashrama.org

Johri, Pradeep Kumar, Educational Thought, New Delhi: Anmol Publications PVT. LTD., 2005, p. 238.

Pani, S.P. and Pattnaik, S.K. Vivekananda, Aurobindo and Gandhi on Education, New Delhi: Anmol Publications PVT. LTD., 2006, pp. 59-60.

Romain Rolland, The Life of Vivekananda, tr. E.K. Malcolm Smith. Kolkata: Advaita Ashrama.

Singh, Y.K. Philosophical Foundation of Education, New Delhi: APH Publishing Corporation, 2007, p. 233.

Teachings of Swami Vivekananda. Kolkata: Advaita Ashrama

The Complete Works of Swami Vivekananda, Nine Volumes. Kolkata: Advaita Ashrama. 